\title{
Bridging Traditions
}


Habent sua fata libelli

\title{
Early Modern Studies Series
}

\author{
GENERAL Editor \\ Michael Wolfe \\ Queens College
}

\section{Editorial Board of Early Modern Studies}

Elaine BeILIN

Framingham State College

Christopher Celenza

Johns Hopkins University

Barbara B. Diefendorf

Boston University

Paula Findlen

Stanford University

SCOT H. HeNDRIX

Princeton Theological Seminary

Jane Campbell Hutchison

University of Wisconsin-Madison

Mary B. McKinley

University of Virginia
Raymond A. Mentzer

University of Iowa

Charles G. Nauert

University of Missouri, Emeritus

Robert V. SCHNUCKer

Truman State University, Emeritus

Nicholas Terpstra

University of Toronto

MARgo TODD

University of Pennsylvania

JAMES TRACY

University of Minnesota

MERRY WIESNER-HANKS

University of Wisconsin-Milwaukee 


\title{
Bridging Traditions
}

\author{
Alchemy, Chemistry, and Paracelsian \\ Practices in the Early Modern Era
}

\author{
Edited by \\ Karen Hunger Parshall, \\ Michael T. Walton, and \\ Bruce T. Moran
}

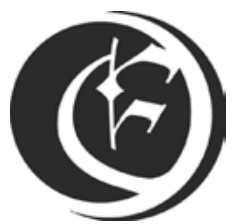

Early Modern Studies 15

Truman State University Press

Kirksville, Missouri 
Copyright (C) 2015 Truman State University Press, Kirksville, Missouri 63501

All rights reserved

tsup.truman.edu

Cover art: "The master and assistant distilling alcohol, a primitive form of reflex condenser," from Conrad Gesner, The newe jewell of health, translated by George Baker (London: H. Denham, 1576). M0012934, Wellcome Library, London.

Cover design: Teresa Wheeler

Library of Congress Cataloging-in-Publication Data

Bridging traditions : alchemy, chemistry, and Paracelsian practices in the early modern era : essays in honor of Allen G. Debus / edited by Karen Hunger Parshall, Michael T. Walton, and Bruce T. Moran.

pages $\mathrm{cm}$.- (Early modern studies ; vol. 15)

Includes bibliographical references and index.

ISBN 978-1-61248-134-0 (library binding : alk. paper) -ISBN 978-1-61248-135-7 (e-book)

1. Chemistry--History. 2. Debus, Allen G. 3. Paracelsus, 1493-1541. I. Parshall, Karen Hunger, 1955- II. Walton, Michael Thomson, 1945-2013 III. Moran, Bruce T. IV. Title: Alchemy, chemistry, and Paracelsian practices in the early modern era.

QD14.B84 2015

$540.9^{\prime} 031--\mathrm{dc} 23$

2014016934

No part of this work may be reproduced or transmitted in any format by any means without written permission from the publisher.

The paper in this publication meets or exceeds the minimum requirements of the American $\mathrm{Na}$ tional Standard for Information Sciences-Permanence of Paper for Printed Library Materials, ANSI Z39.48-1992. 
To the memory of Allen G. Debus and Michael T. Walton. 
